Supplementary Information

\title{
Solution-Processed Layered Hexagonal Boron Nitride Dielectrics: A Route toward Fabrication of High Performance Flexible Devices
}

\author{
Bikesh Gupta and H. S. S. Ramakrishna Matte* \\ Energy Materials Laboratory, Centre for Nano and Soft Matter Sciences, Jalahalli, \\ Bengaluru 560013, India \\ *E-mail: matte@cens.res.in, krishnamatte@gmail.com \\ Phone: +91-80-23084264. Fax: +91-80-28382044
}

\section{Section S1: Detailed characterization of h-BN dispersions}

\section{Concentration determination}

To determine the concentration of h-BN dispersions, $4 \mathrm{ml}$ of h-BN dispersion is dispensed into cleaned $5 \mathrm{ml}$ beaker. The solvent is dried off by heating the dispersion at $80{ }^{\circ} \mathrm{C}$ in hot air oven. The residual mass in the beaker is precisely weighed to obtain the concentration of the dispersions. The concentrations obtained from gravimetry should be correlated with the concentrations obtained from UV-Visible spectroscopy. To obtain the concentration from UV-Visible spectra, it is important to find the absorption coefficient as shown in equation 1 .

$A=\varepsilon c l$

To obtain the absorption coefficient of the h-BN dispersions, UV-Visible spectra are recorded by diluting the dispersions by different factors. The extinction coefficients are obtained for series of dispersions and are shown in Figure S1. As discussed by Coleman at al., the absorbance spectra obtained from UV-Visible spectroscopy has two components namely absorption and scattering and is shown in equation $2 .{ }^{1}$

$\varepsilon=\alpha+\sigma$

where $\varepsilon$ is extinction coefficient, $\alpha$ is absorption coefficient and $\sigma$ is scattering coefficient. In any dispersions along with intrinsic absorption from the material, scattering component also arises due to factors like sheet dimensions, concentrations etc. The concentrations from UVVisible spectra using extinction coefficient would lead to erroneous result while determining the concentrations. To address this and to remove the scattering component in $\mathrm{MoS}_{2}$ dispersions absorption coefficient is determined at the absorbance peak of $\mathrm{MoS}_{2}{ }^{2}$ This strategy holds true if there are discernible absorbance peak in the UV-Visible spectra. But due to cut off wavelength of the solvent, the absorbance peak of h-BN in 2-butanone is not 
observed. So the extinction coefficient h-BN dispersions are calculated at $400 \mathrm{~nm}$ for three different concentrations (as the scattering component varies with concentration) extinction coefficient is determined and is shown in Figure S1. The bath sonicated dispersions has average of $1002 \mathrm{ml} \mathrm{mg}^{-1} \mathrm{~m}^{-1}$ extinction coefficient and the concentration obtained using UVVisible and gravimetry are in close agreement with less than $15 \%$ of deviation and the results are shown in Figure S2 (a). However, the probe sonicated dispersions demonstrated varied extinction coefficient depending on the concentration of dispersion. For lower concentrations the extinction coefficient was similar to bath sonicated dispersions $\left(1002 \mathrm{ml} \mathrm{mg}^{-1} \mathrm{~m}^{-1}\right)$ and for higher concentrations the values obtained are $1403 \mathrm{ml} \mathrm{mg}^{-1} \mathrm{~m}^{-1}$ and $1730 \mathrm{ml} \mathrm{mg}^{-1} \mathrm{~m}^{-1}$. The concentrations obtained employing Beer Lambert and gravimetry in probe sonicated dispersion are shown in Figure S2 (b). The concentrations determined by both the methods are in close agreement with less than $10 \%$ deviation. In conclusion, $\varepsilon_{400}$ of $1002 \mathrm{ml} \mathrm{mg}^{-1} \mathrm{~m}^{-}$ ${ }^{1}$ can be used with concentration less than $1.5 \mathrm{mg} \mathrm{ml}^{-1}$ whereas $\varepsilon_{400}$ of $1403 \mathrm{ml} \mathrm{mg}^{-1} \mathrm{~m}^{-1}$ and $1730 \mathrm{ml} \mathrm{mg}^{-1} \mathrm{~m}^{-1}$ are ideal to be used in the case of $1.5 \mathrm{mg} \mathrm{ml}^{-1}$ to $3.0 \mathrm{mg} \mathrm{ml}^{-1}$, and 3.0 to 3.9 $\mathrm{mg} \mathrm{ml} \mathrm{m}^{-1}$ respectively. However, the use of given extinction coefficient in determining the hBN concentrations obtained from different experimental conditions is not encouraged.
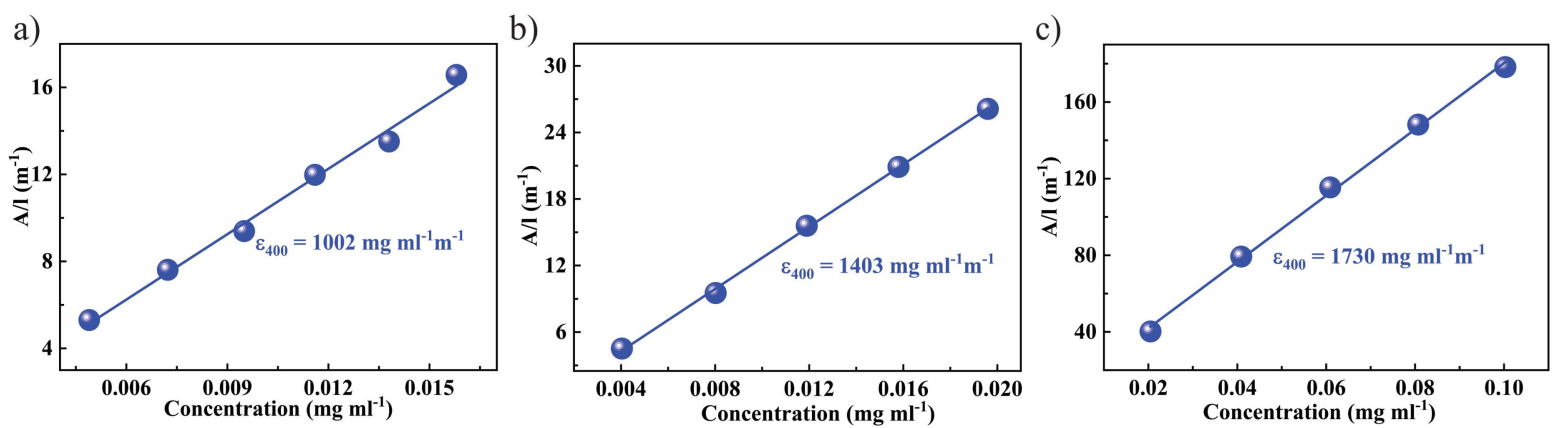

Figure S1. Extinction coefficient determination of h-BN.
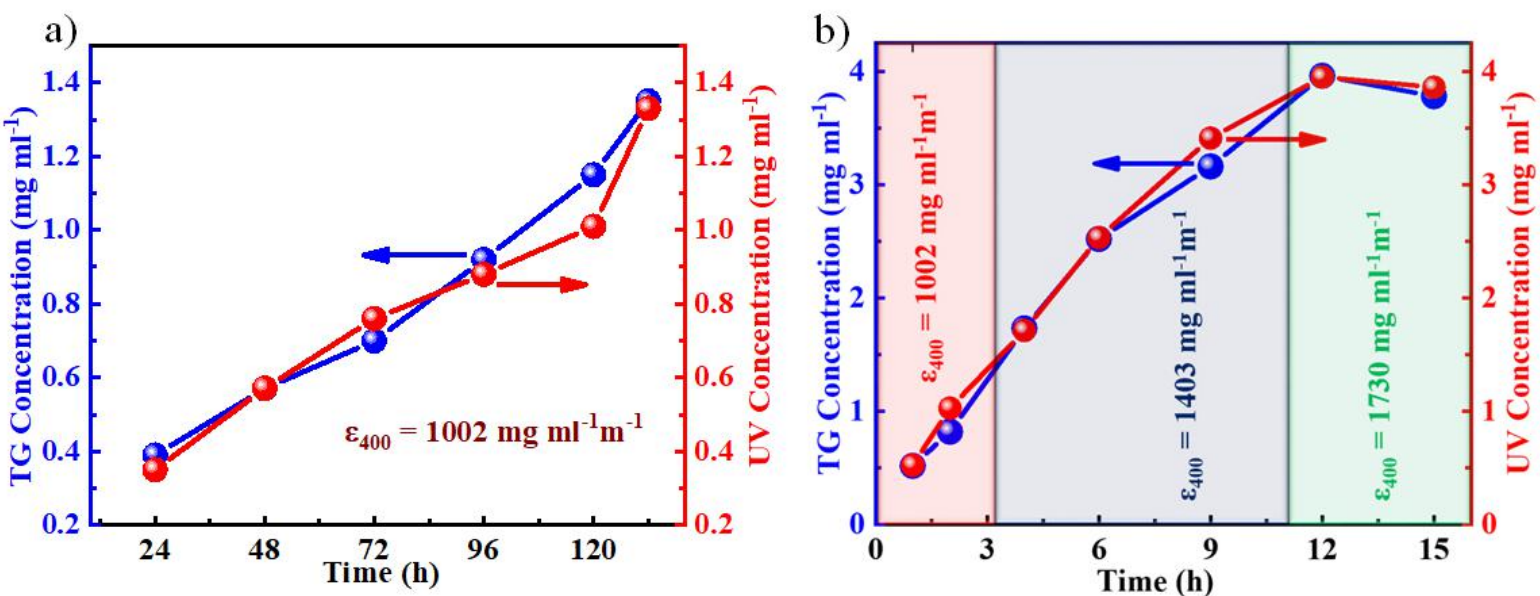

Figure S2. Comparison of concentration determined from UV-Visible spectroscopy and gravimetry where (a) comparison of concentration of h-BN dispersions obtained from bath sonication with $\mathrm{C}_{\mathrm{i}}=100 \mathrm{mg} \mathrm{ml}^{-1}$ (b) comparison of concentration of h-BN dispersions obtained from probe sonication with $\mathrm{C}_{\mathrm{i}}=100 \mathrm{mg} \mathrm{ml}^{-1}$. 


\section{Cut-off wavelength of solvent}

It is important to know the UV-Visible cut-off wavelength of the solvent being used. It is because below this wavelength the solvent itself absorbs all the light and if the absorbance peak of the material being investigated falls below the cut-off wavelength of the solvent then the material absorbance peak may not be evident in the UV-Visible spectra. To determine the cut-off wavelength of the 2-butanone, UV-Visible spectra is recorded and it is found that 2butanone has cut-off wavelength at $340 \mathrm{~nm}$ (Figure S3 (a)). This impedes the calculation of h-BN band gap as the solvent cut-off wavelength precedes the absorbance peak of h-BN. In order to find the band gap of h-BN, the dispersions were drop casted onto quartz glass (UVVisible cut off wavelength $\sim 180 \mathrm{~nm}$ ) and UV-Visible spectra was recorded and is shown in Figure S3 (b). Form the UV-Visible spectra it is clearly evident that exfoliated h-BN demonstrate its characteristic peak at $205 \mathrm{~nm}$ with corresponding band gap of about $6.04 \mathrm{eV}$.

a)

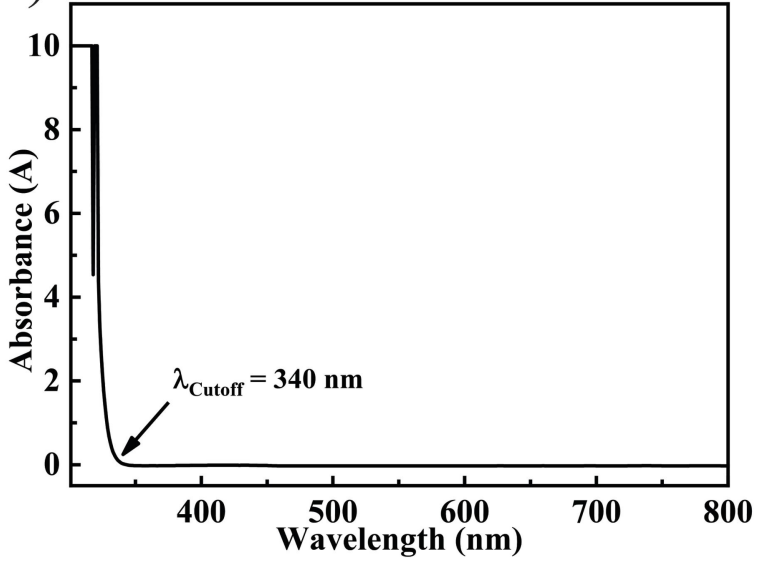

b)

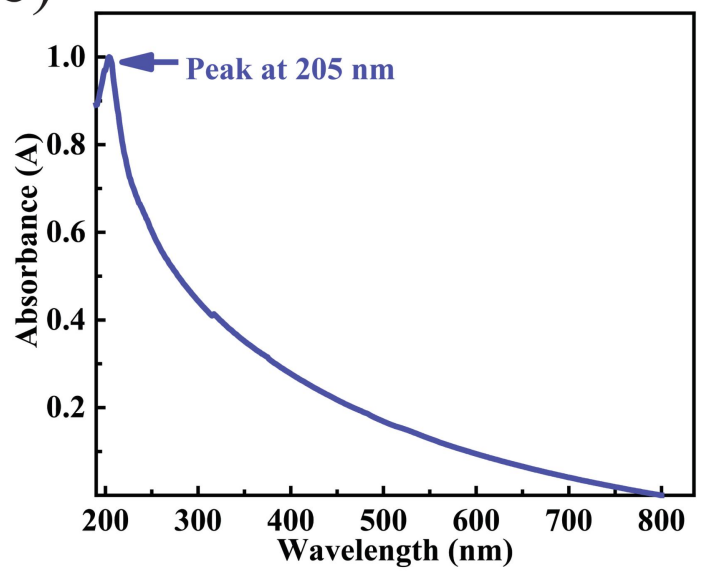

Figure S3. Absorbance spectra (a) of pure solvent demonstrating the cut-off wavelength of 2Butanone (b) of drop casted h-BN dispersions onto quartz substrate.

\section{h-BN dispersions obtained from bath sonication}

The effect of $\mathrm{t}_{\mathrm{s}}$ on other $\mathrm{C}_{\mathrm{i}}$ like 10,30,50 $\mathrm{mg} \mathrm{ml}^{-1}$ has also been evaluated. As can be seen in Figure $\mathrm{S} 4$, as $\mathrm{t}_{\mathrm{s}}$ increases correspondingly there is an increase in the absorbance value suggesting $t_{\mathrm{s}}$ has positive impact on stabilizing higher $\mathrm{C}_{\mathrm{f}}$. The maximum $\mathrm{C}_{\mathrm{f}}$ obtained from 10 $\mathrm{mg} \mathrm{ml} l^{-1}, 30 \mathrm{mg} \mathrm{ml}^{-1}$ and $50 \mathrm{mg} \mathrm{ml}^{-1}$ is $0.12 \mathrm{mg} \mathrm{ml}^{-1}, 0.344 \mathrm{mg} \mathrm{ml}^{-1}, 0.822 \mathrm{mg} \mathrm{ml}^{-1}$ respectively (inset in Figure S4). It is to note that, none of the $\mathrm{C}_{\mathrm{i}}$ led to saturation of h-BN dispersions upto the considered duration of sonication suggesting further possibility of increasing the concentration of h-BN in 2-butanone. 

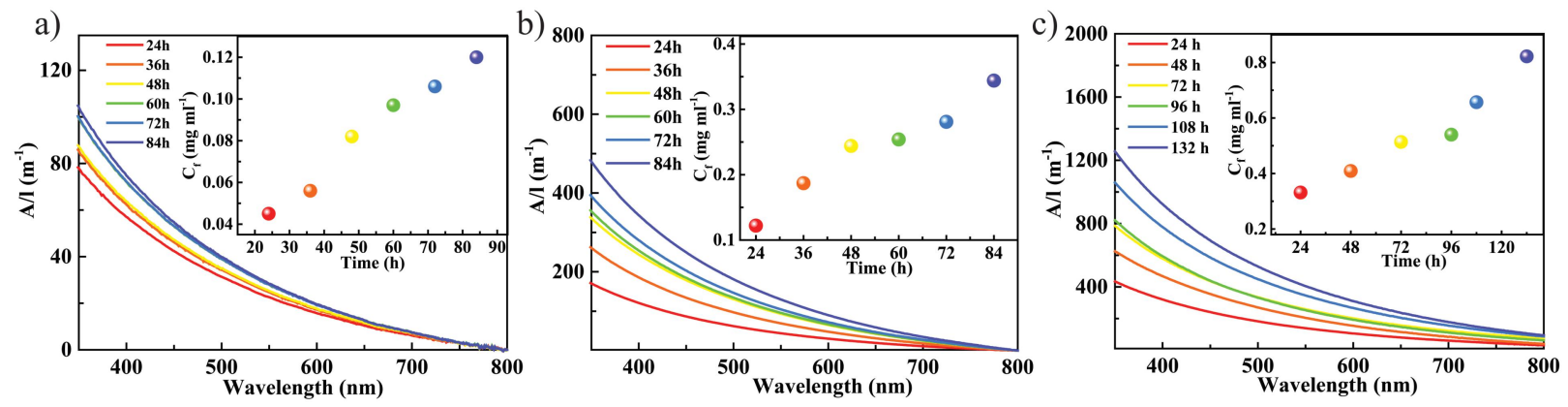

Figure S4. Absorbance spectra of h-BN dispersions obtained from low power bath sonication. Time dependent absorbance spectra obtained from (a) $\mathrm{C}_{\mathrm{i}}=10 \mathrm{mg} \mathrm{ml}^{-1}$ (b) $\mathrm{C}_{\mathrm{i}}=30 \mathrm{mg} \mathrm{ml}^{-1}$ (c) $\mathrm{C}_{\mathrm{i}}=50 \mathrm{mg} \mathrm{ml}^{-1}$. Inset shows the corresponding concentration of h-BN dispersions.

\section{Microscopic characterization of h-BN dispersions from bath sonication}

a)

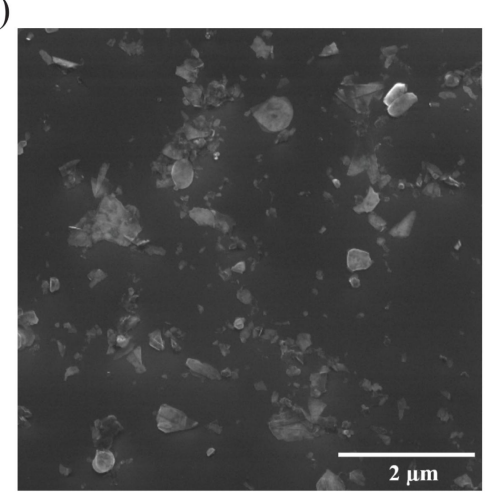

b)

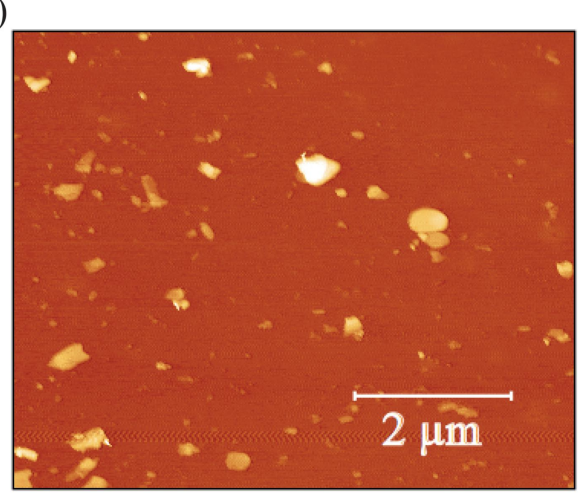

c)

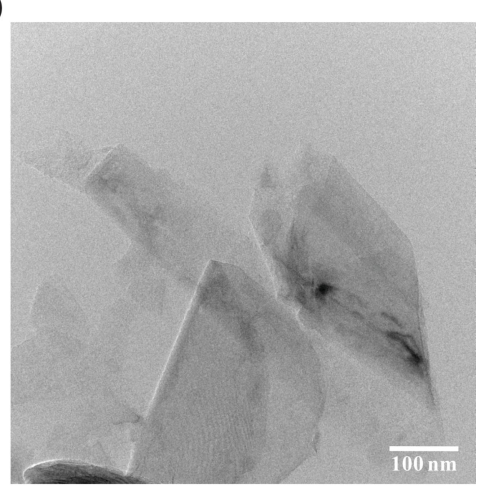

Figure S5.Characterization of h-BN dispersions obtained from bath sonication for $\mathrm{C}_{\mathrm{i}}$ of 100 $\mathrm{mg} \mathrm{ml} \mathrm{m}^{-1}$ sonicated for $132 \mathrm{~h}$. (a) FESEM micrograph of exfoliated h-BN sheets. (b) AFM micrograph of exfoliated h-BN sheets. (c) TEM micrograph of exfoliated h-BN sheets.

\section{h-BN dispersions obtained from probe sonication}

The effect of $t_{s}$ on other $C_{i}$ like $10 \mathrm{mg} \mathrm{ml}^{-1}, 30 \mathrm{mg} \mathrm{ml}^{-1}$, and $50 \mathrm{mg} \mathrm{ml}^{-1}$ have also been evaluated for probe sonication based exfoliation. As can be seen in Figure $S 6$, as $t_{s}$ increases correspondingly there is an increase in the absorbance value suggesting $t_{s}$ has positive impact on stabilizing higher $C_{f}$. The maximum $C_{f}$ obtained from $10 \mathrm{mg} \mathrm{ml}^{-1}, 30 \mathrm{mg} \mathrm{ml}^{-1}$ and $50 \mathrm{mg}$ $\mathrm{ml}^{-1}$ is $0.19,0.61,1.47 \mathrm{mg} \mathrm{ml}^{-1}$ respectively (inset in Figure S6). It is to note that, none of the $\mathrm{C}_{\mathrm{i}}$ led to saturation of $\mathrm{h}-\mathrm{BN}$ dispersions upto the considered duration of sonication suggesting further possibility of increasing the concentration of h-BN in 2-butanone. 

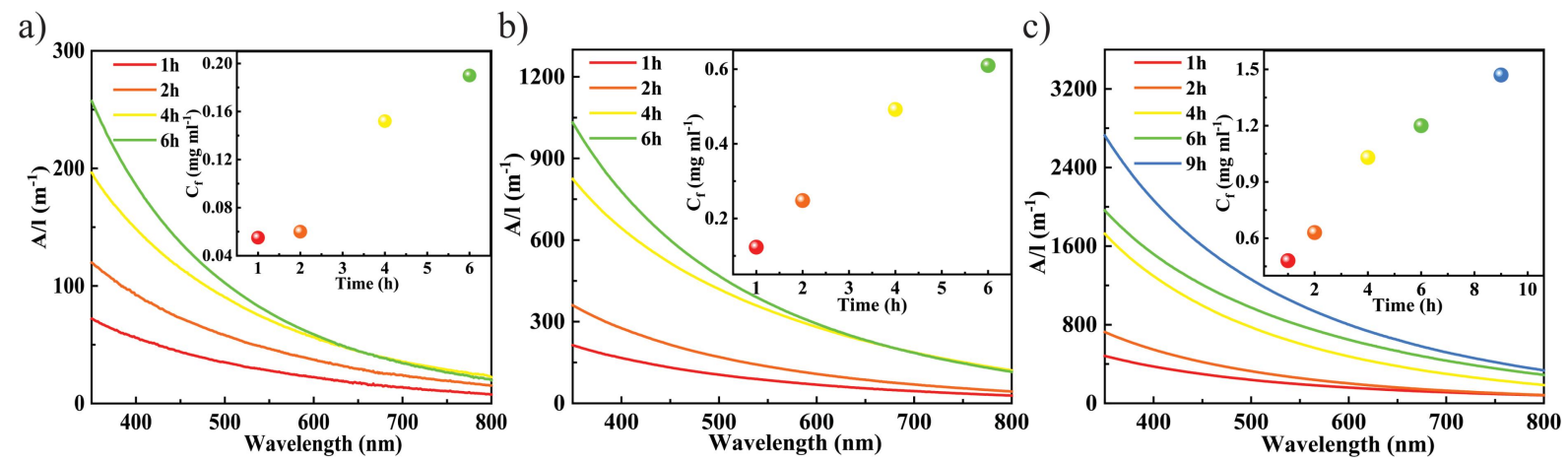

Figure S6. Absorbance spectra of h-BN dispersions obtained from probe sonication. Time dependent absorbance spectra obtained from (a) $\mathrm{C}_{\mathrm{i}}=10 \mathrm{mg} \mathrm{ml}^{-1}$ (b) $\mathrm{C}_{\mathrm{i}}=30 \mathrm{mg} \mathrm{ml}^{-1}$ (c) $\mathrm{C}_{\mathrm{i}}=50$ $\mathrm{mg} \mathrm{ml}^{-1}$. Inset shows the corresponding concentration of $\mathrm{h}-\mathrm{BN}$ dispersions.

a)

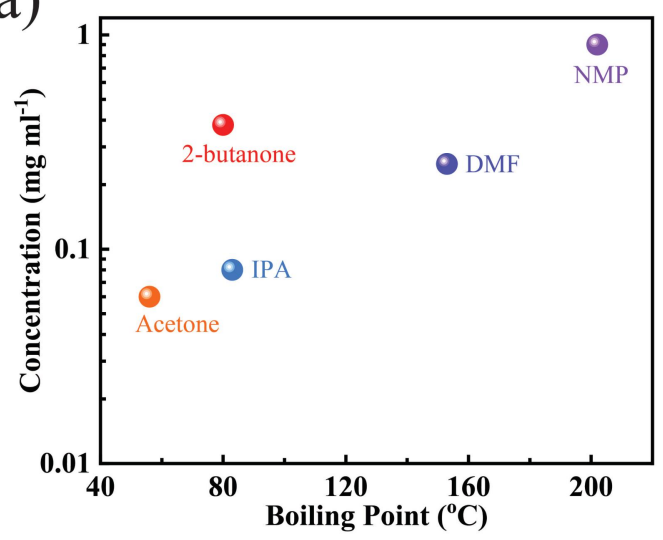

b)

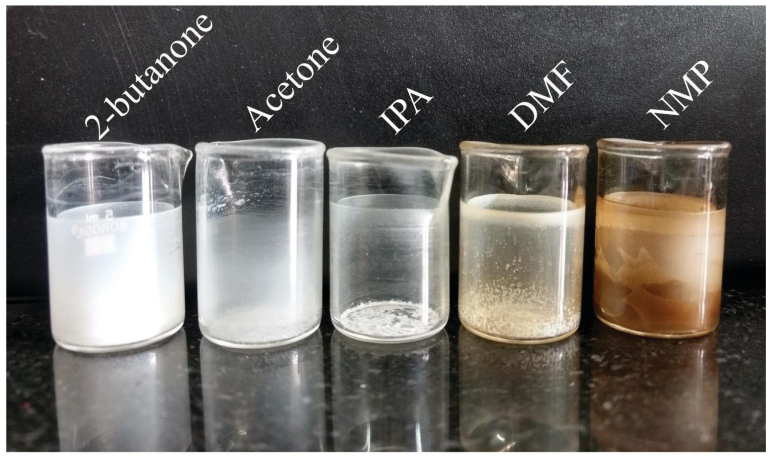

Fig S7. (a) Comparison of the concentration of h-BN dispersions in different solvents with different boiling points (b) residue obtained after boiling off the solvents at their respective boiling points.

The exfoliation of h-BN in other solvents like IPA, acetone, DMF and NMP is performed under similar experimental condition $\left(\mathrm{C}_{\mathrm{i}}\right.$ of $30 \mathrm{mg} \mathrm{ml}^{-1}$ sonicated for $2 \mathrm{~h}$ at $40 \%$ power $)$ as that of 2-butanone. Compared to IPA $\left(0.08 \mathrm{mg} \mathrm{ml}^{-1}\right)$ and acetone $\left(0.06 \mathrm{mg} \mathrm{ml}^{-1}\right)$, the concentration of h-BN in 2-butanone $\left(0.38 \mathrm{mg} \mathrm{ml}^{-1}\right)$ is at least five times more suggesting 2butanone is better for h-BN exfoliation with low boiling point (Figure S7 (a)). But the concentration of h-BN in NMP is still higher than 2-butanone (Figure S7 (a)). It is to note that, the concentration of h-BN dispersion is calculated using the protocol discussed in section $\mathrm{S} 1$. To briefly recall, the concentrations are calculated by drying off $4 \mathrm{ml}$ of dispersions at their respective boiling points (2-butanone: $80^{\circ} \mathrm{C}$, Acetone: $55^{\circ} \mathrm{C}$, IPA: $83{ }^{\circ} \mathrm{C}$, DMF: $153{ }^{\circ} \mathrm{C}$ and NMP: $202{ }^{\circ} \mathrm{C}$ ). As it can observed in Figure $\mathrm{S} 7$ (b) the residual h-BN is brown in colour in NMP unlike 2-butanone and IPA after dying the solvent. This suggest that, h-BN degrades (probably converts into boron oxide) in NMP when heated at higher temperature. It is worth noting that, though in NMP one may obtain high concentrations of h-BN but the degradation of h-BN in NMP while removing the solvent impedes its application in device fabrication. 
However, this can be avoided by solvent exchange protocol which is again a cumbersome process.

\section{Stability studies of the solvent under probe sonication}

To evaluate the stability of solvent against high energy sonication, 2-butanone is sonicated at $80 \%$ power for $2 \mathrm{~h}$ in the regular setup and the UV-Visible spectra are recorded. No evident change is the spectra are discernable compared to the fresh solvent suggesting the solvent is stable against high energy sonication. It is important to note that, in the systems like h-BN were the exfoliation is energy intensive (as discussed in main paper), it is inevitable to use solvent which can sustain against high energy sonication.

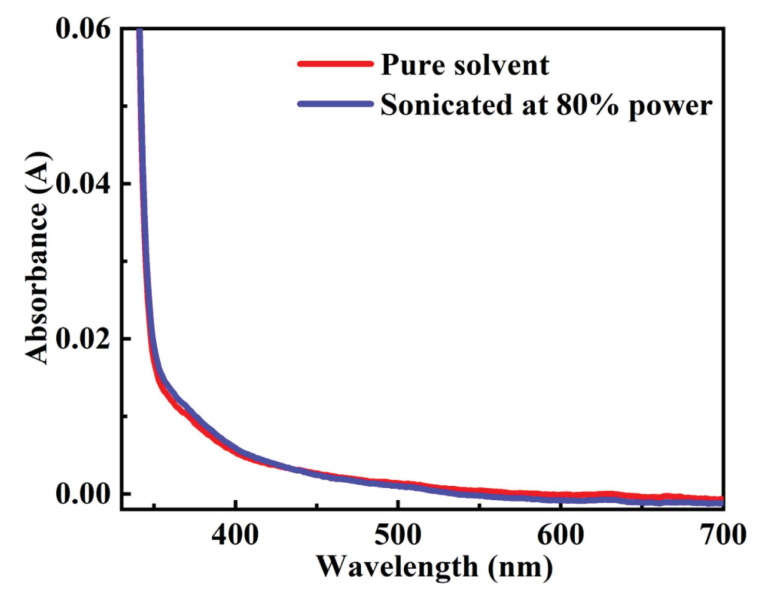

Figure S8. Absorbance spectra of 2-butanone sonicated at $80 \%$ power and un-sonicated solvent.

a)

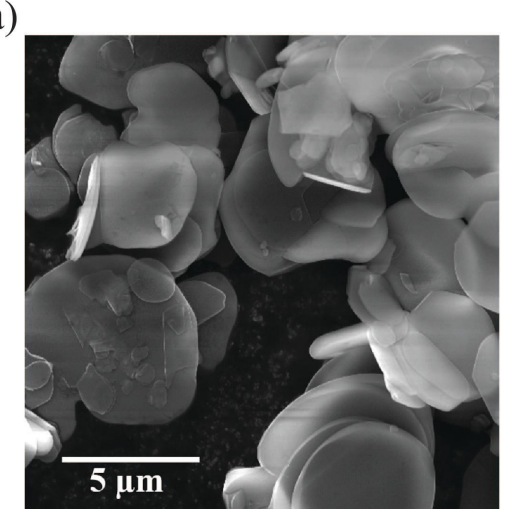

b)

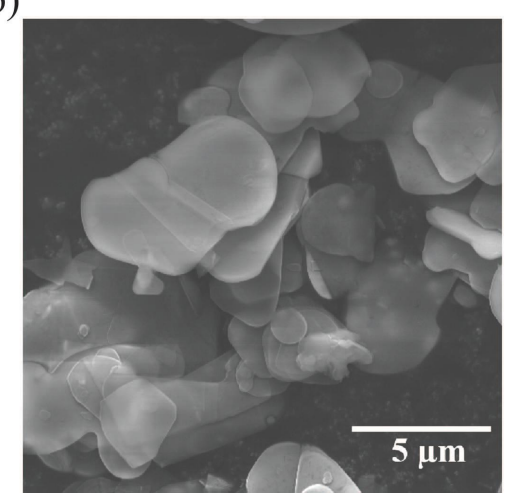

c)

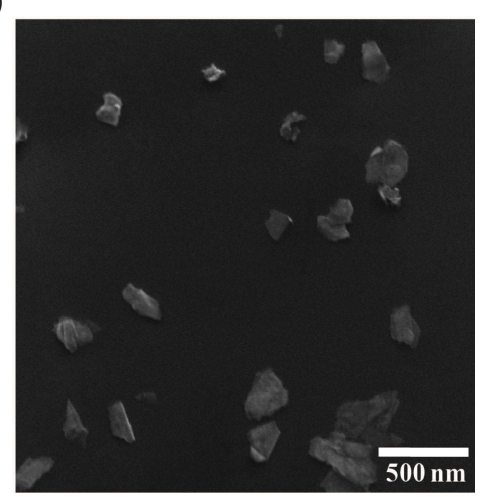

Fig S9. FESEM micrograph of (a) bulk h-BN powder (b) refurbished h-BN powder (c) exfoliated h-BN nanosheets using probe sonication. 


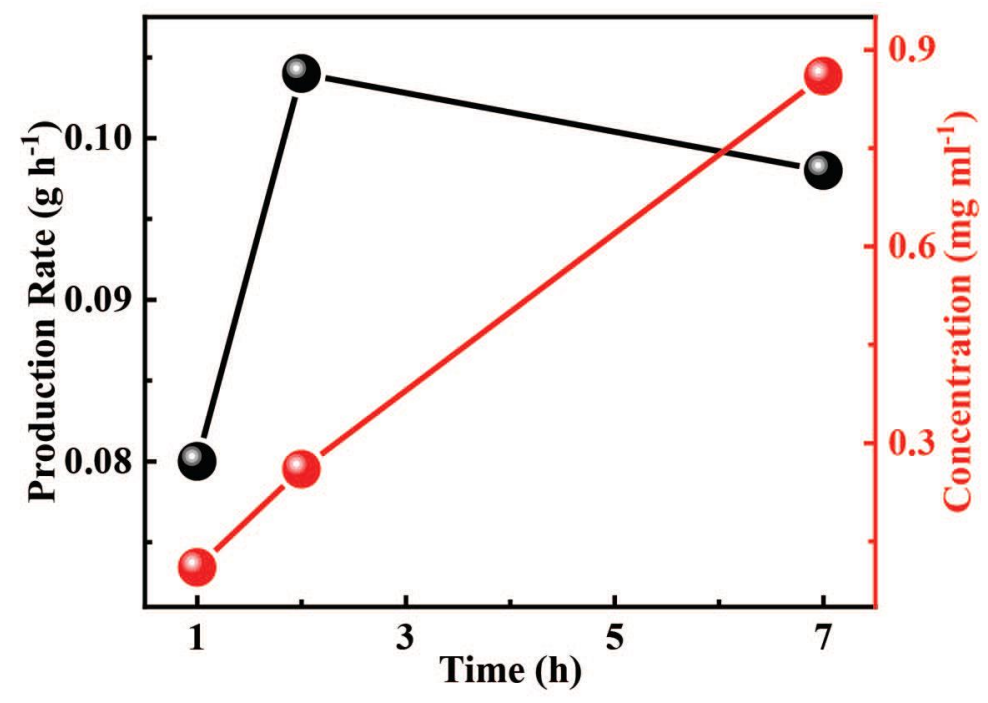

Fig S10. Production rate determination for as-obtained h-BN powder.

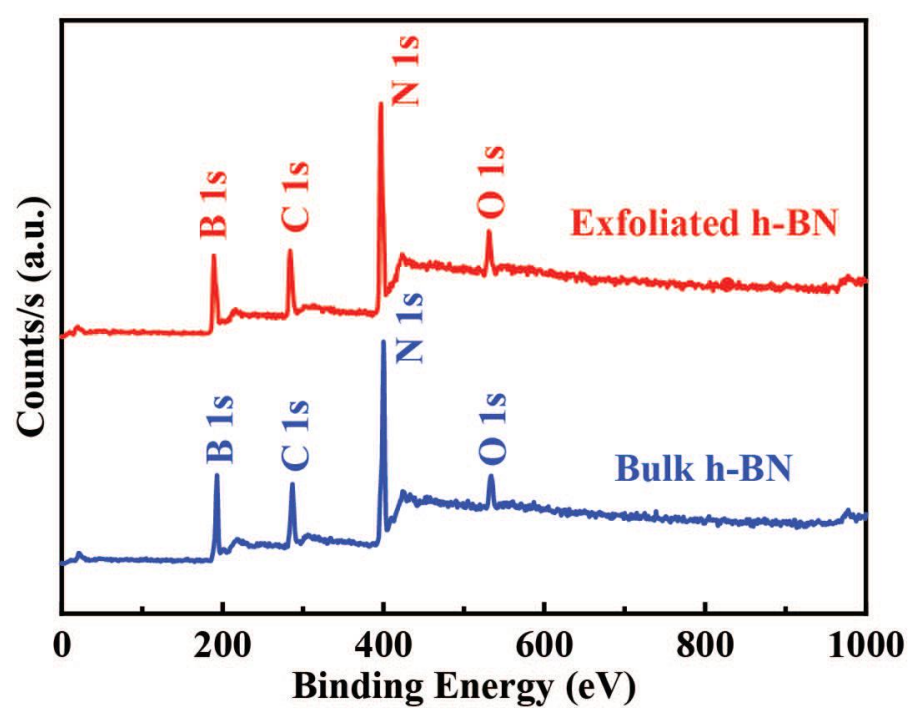

Fig S11. XPS survey scan of bulk and exfoliated h-BN. 


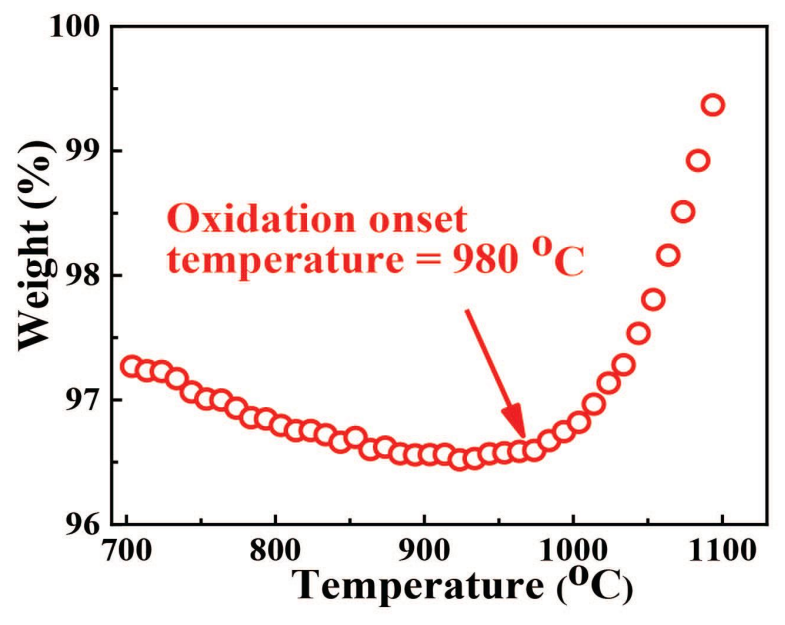

Fig S12. Enlarged view of TGA in the region of $700{ }^{\circ} \mathrm{C}$ to $1100{ }^{\circ} \mathrm{C}$ suggesting the oxidation of exfoliated h-BN starts at $980{ }^{\circ} \mathrm{C}$.

Thin film fabrication using electrophoretic deposition(ED)

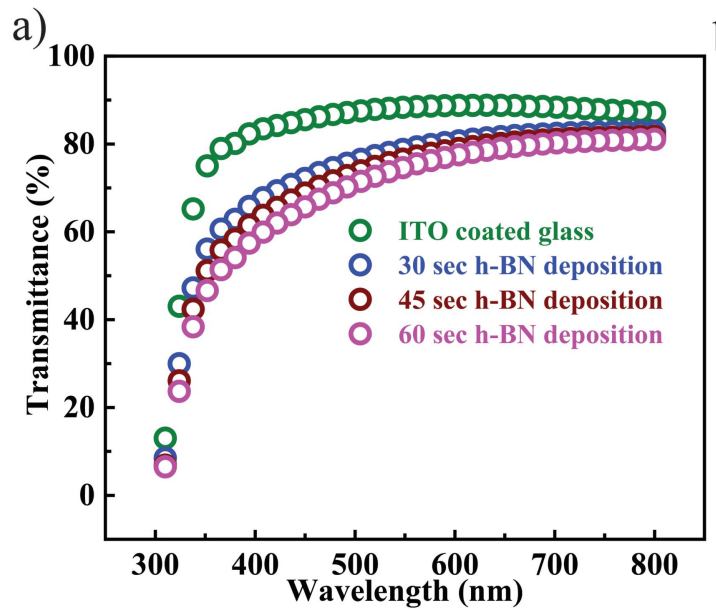

b)

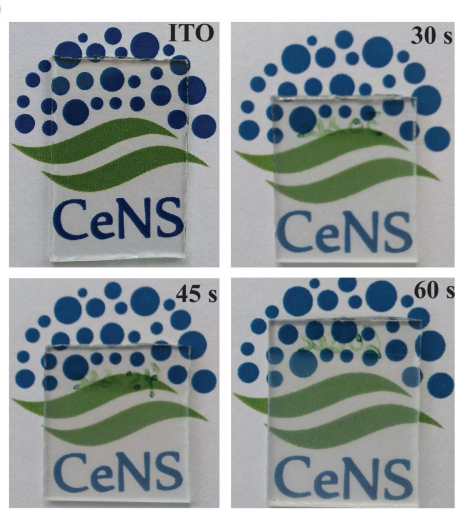

Figure S13. UV-Visible spectra of h-BN films showing transmittance of fabricated films at different deposition times (b) corresponding optical images of h-BN films.

a)

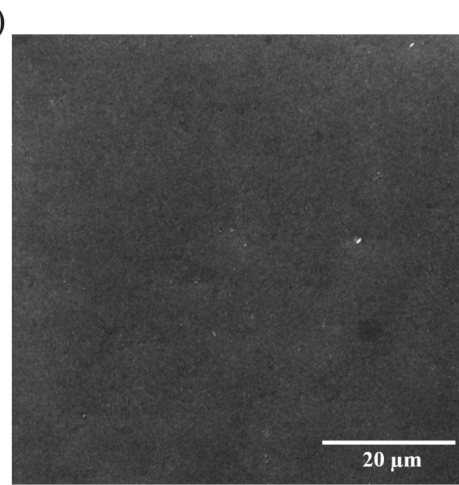

b)

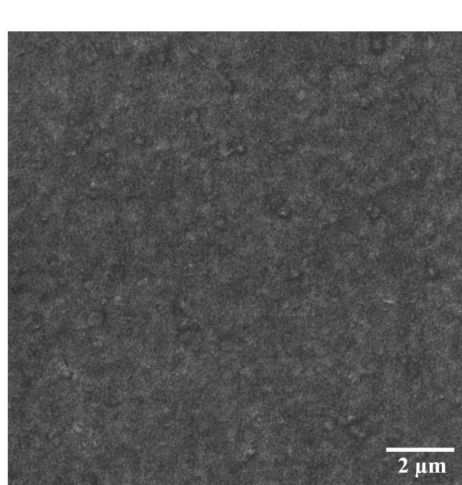

c)

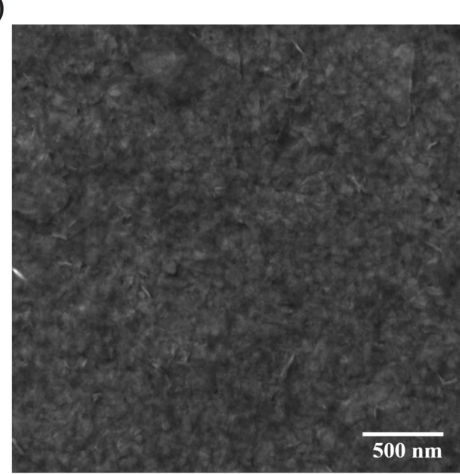

Figure S14. FESEM images at different magnification of h-BN films fabricated for $15 \mathrm{~s}$ of electrophoretic deposition. 
To determine the quality of the films obtained from ED, various characterizations have been carried out. FESEM micrographs at different magnifications for the films obtained for the ED of $\mathrm{t}=15 \mathrm{~s}$, is shown in Figure S9. It is clearly evident that films are continuous and have full coverage over the substrate.

This is further validated from the elemental mapping of Boron (B) and Nitrogen (N) using FESEM-EDS and is shown in Figure S10. As can be seen B and N are uniformly distributed over the entire region for the films fabrication at different deposition times $(15 \mathrm{~s}, 30 \mathrm{~s}, 45 \mathrm{~s}$ and $60 \mathrm{~s})$.

\section{a)}

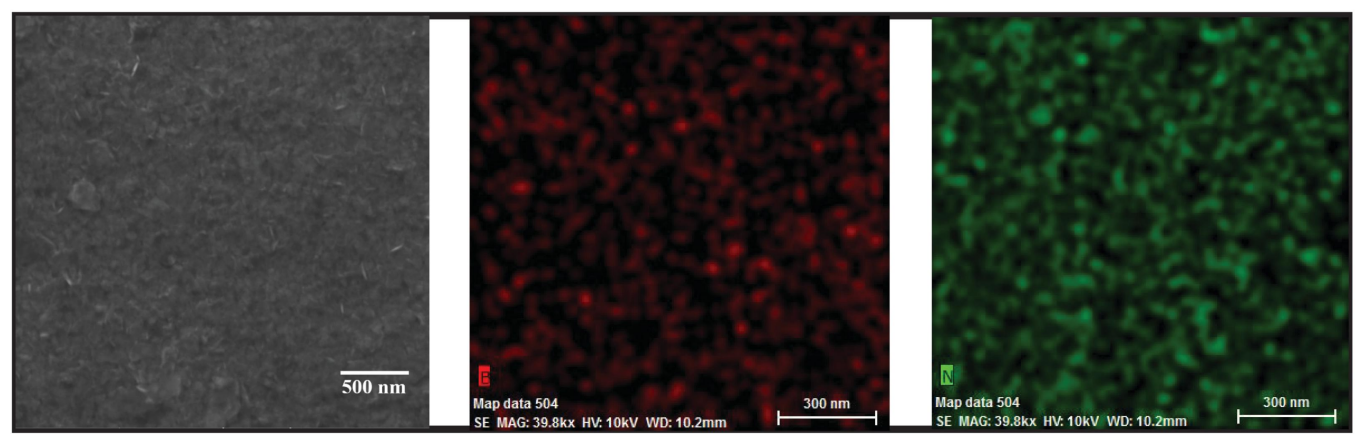

b)

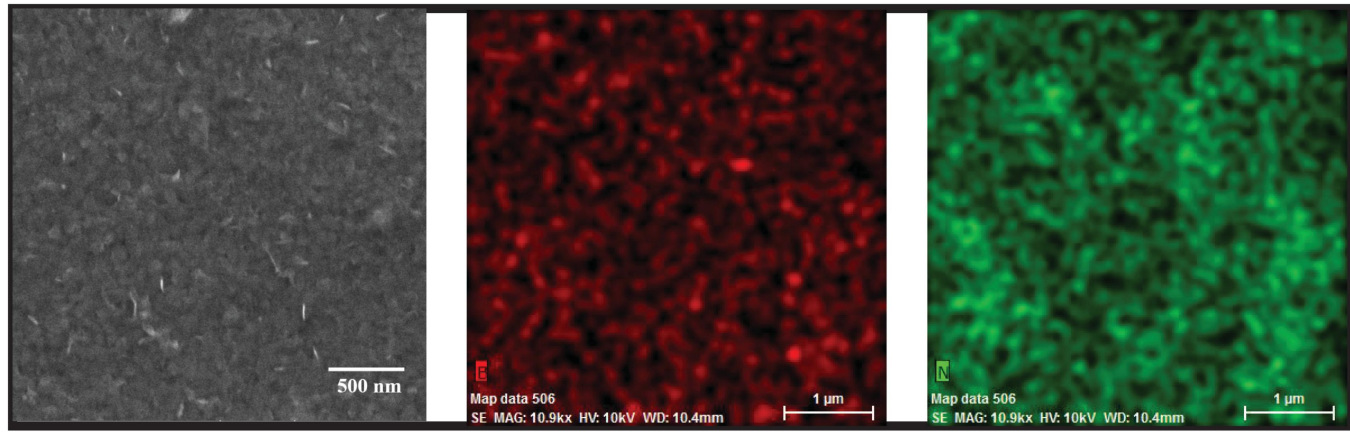

c)

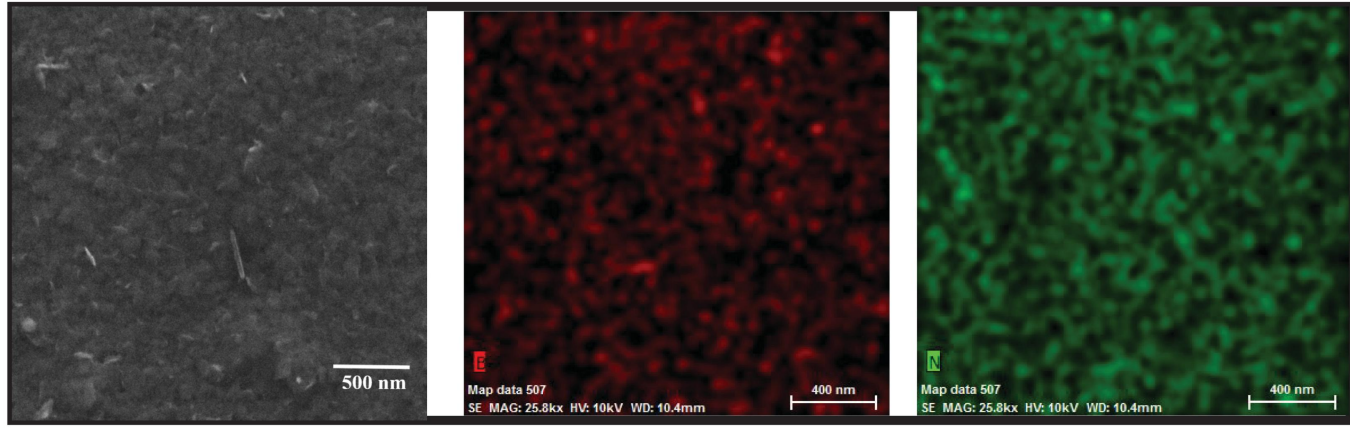

d)

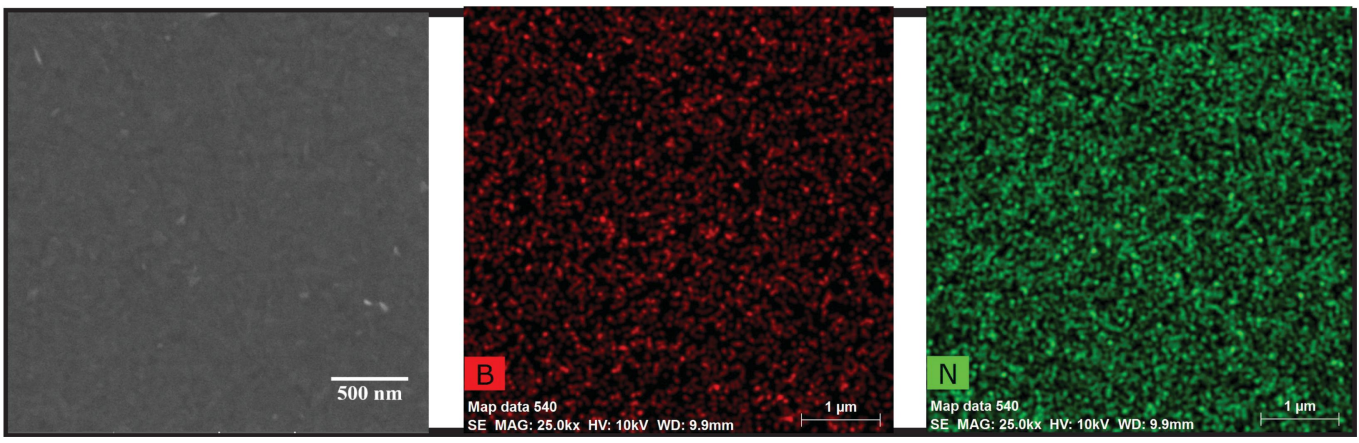

Figure S15. FESEM images of h-BN films fabricated at different deposition times and corresponding elemental mapping of boron and nitrogen (a) $15 \mathrm{~s} \mathrm{(b)} 30 \mathrm{~s}$ (c) $45 \mathrm{~s} \mathrm{(d)} 60 \mathrm{~s}$. 
a)

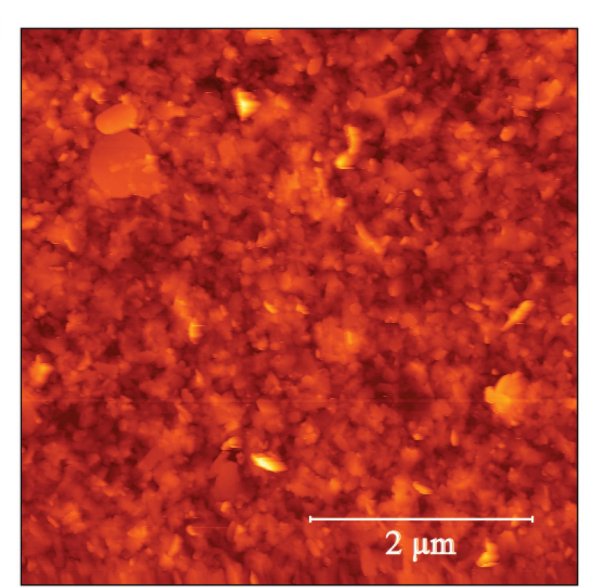

c)

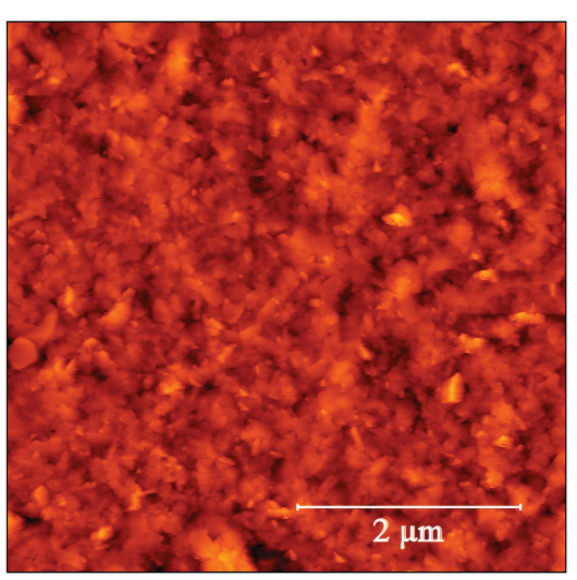

b)

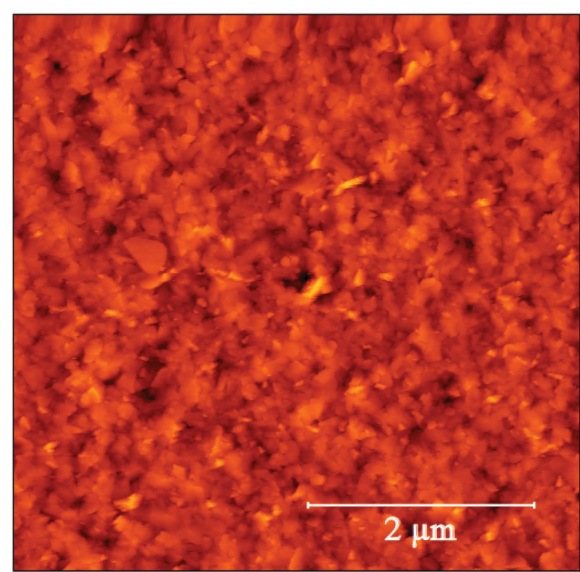

d)

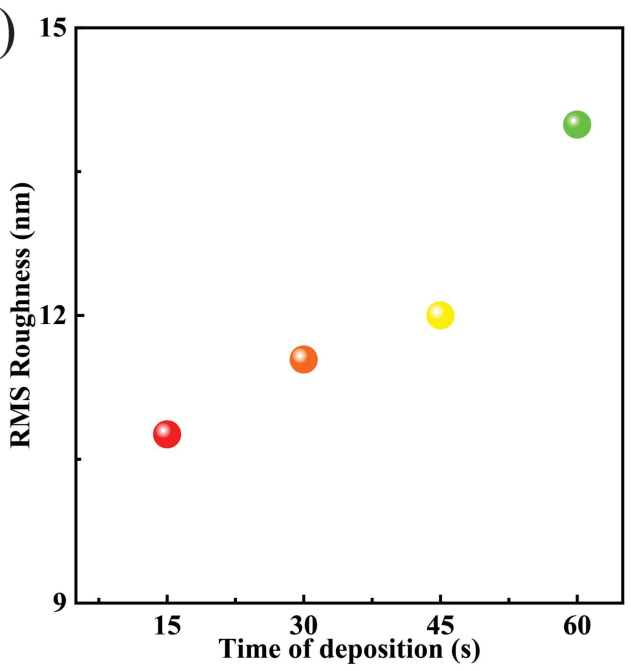

Figure S16. AFM images of h-BN films fabricated at different deposition times (a) $30 \mathrm{~s}$ (b) $45 \mathrm{~s}(\mathrm{c}) 60 \mathrm{~s}$ (d) corresponding films roughness.

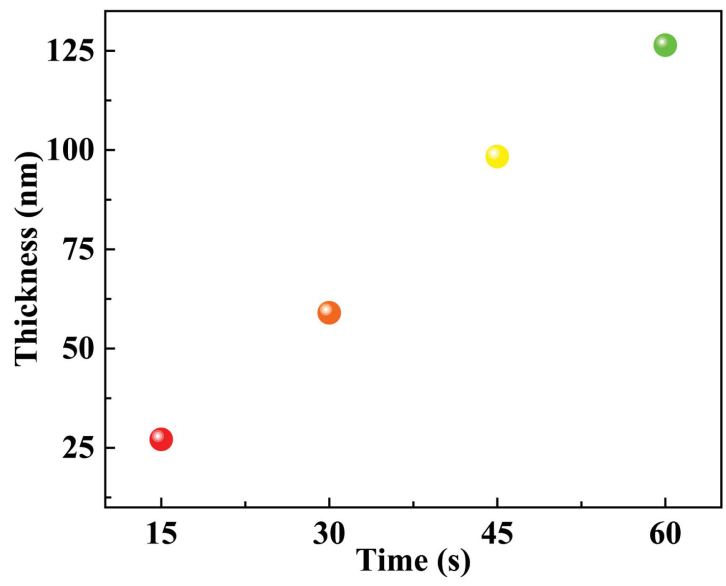

Figure S17. Film thickness as a function of deposition time. 
a)

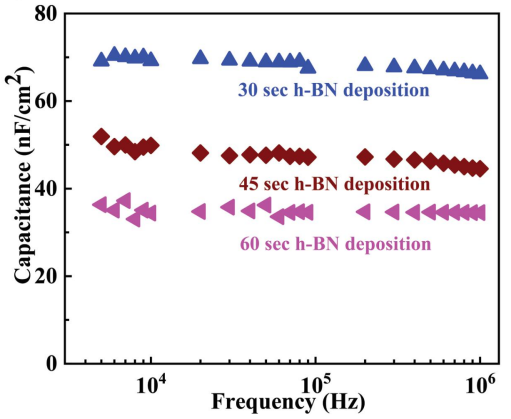

b)

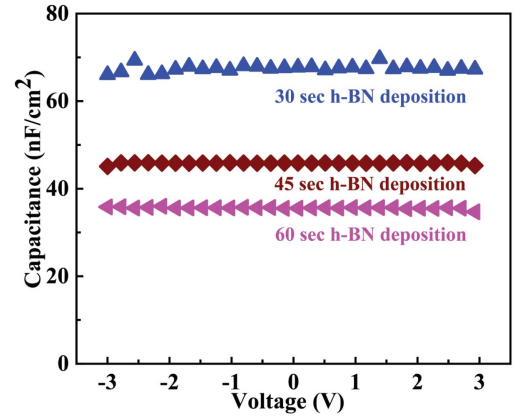

c)

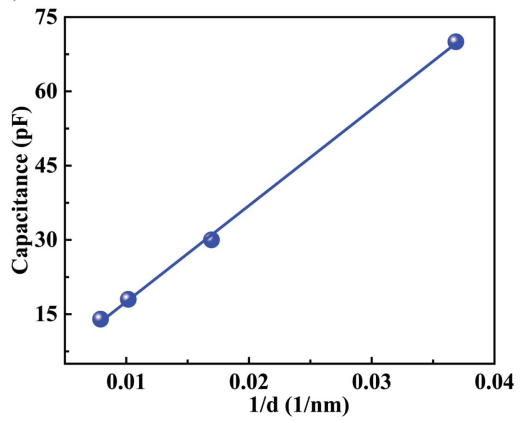

Figure S18. (a) Capacitance vs Frequency plot of h-BN films fabricated at different deposition times (b) Capacitance vs Voltage plot of h-BN films fabricated at different deposition times (c) capacitance as a function of inverse of film thickness.

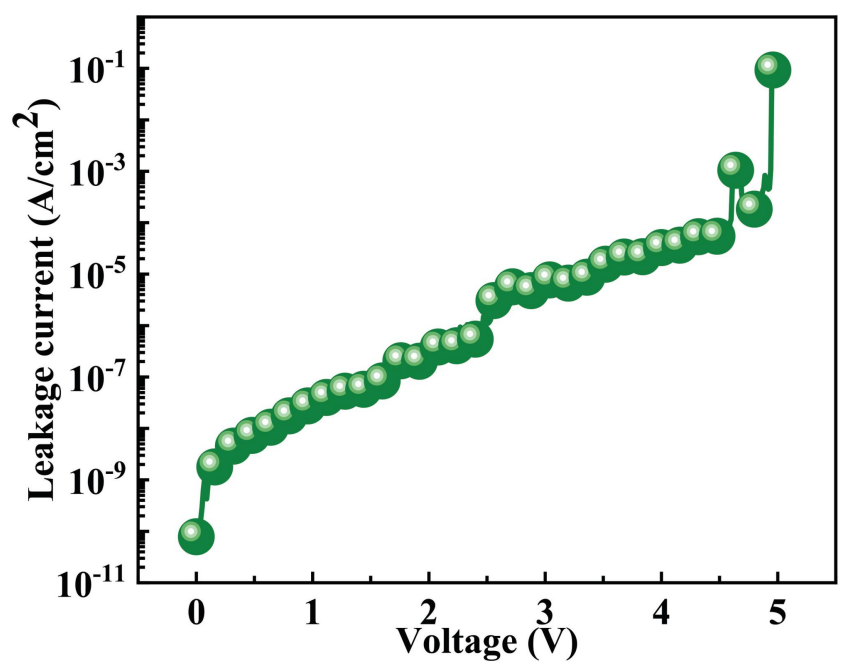

Figure S19. I vs V characteristics of h-BN films fabricated demonstrating the breakdown voltage of the capacitor.

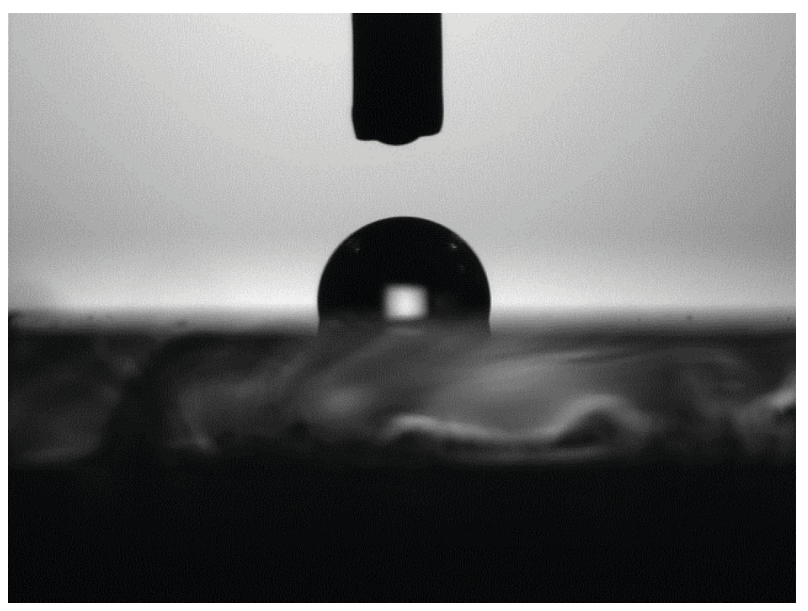

Figure S20. Contact angle measured on film fabricated by depositing h-BN for $15 \mathrm{~s}$. The measured contact angle is $101^{\circ}$, suggesting the hydrophobic nature of h-BN. 
a)

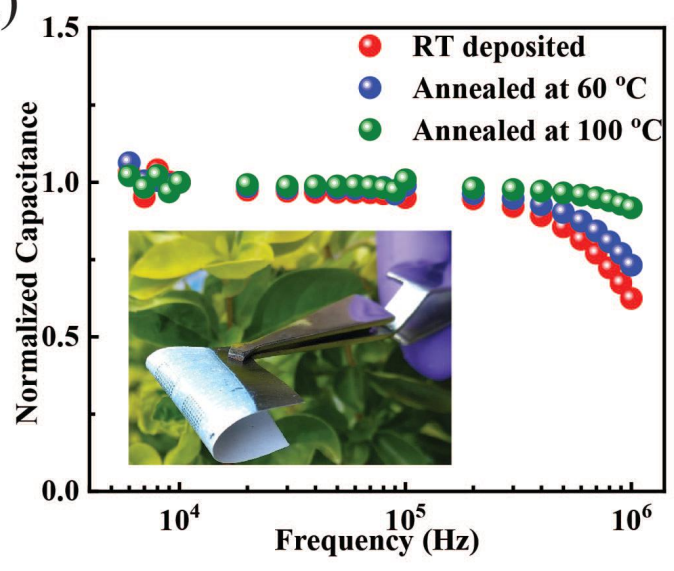

b)

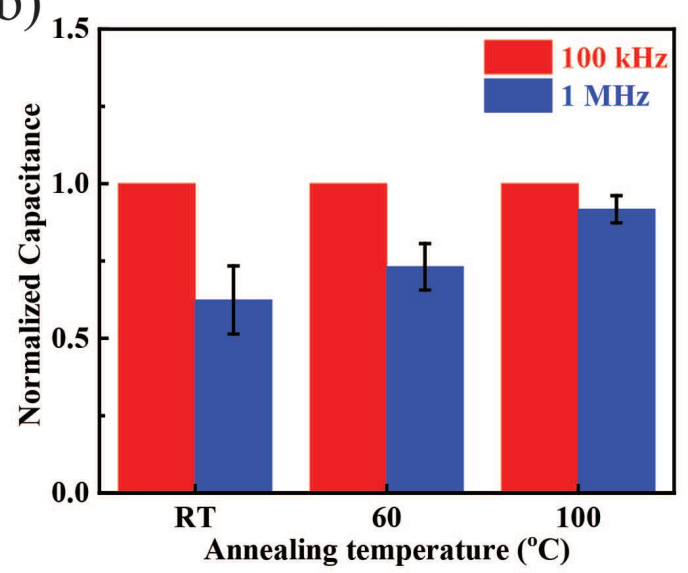

Fig S21. (a) Normalized C-F of paper based capacitors annealed at different temperatures. Inset shows the paper based h-BN capacitors. (b) Bar plot depicting the change in capacitance of paper based h-BN capacitors as a function of annealing temperature.

Table S1. Comparison of HSP values of 2-butanone and h-BN.

\begin{tabular}{|l|l|l|}
\hline & h-BN & 2-butanone \\
\hline Range of $\delta_{\mathrm{D}}\left(\mathrm{MPa}^{1 / 2}\right)$ & $17-19$ & 16 \\
\hline Range of $\delta_{\mathrm{P}}\left(\mathrm{MPa}^{1 / 2}\right)$ & $4-10$ & 9 \\
\hline Range of $\delta_{\mathrm{H}}\left(\mathrm{MPa}^{1 / 2}\right)$ & $4-10$ & 5.1 \\
\hline
\end{tabular}


Table S2. Table showing the concentration of h-BN in different solvent systems.

\begin{tabular}{|c|c|c|c|c|c|}
\hline $\begin{array}{l}\text { Sl. } \\
\text { No }\end{array}$ & Solvent & $\begin{array}{l}\text { Processing } \\
\text { technique }\end{array}$ & $\begin{array}{l}\text { Boiling } \\
\text { point }\end{array}$ & Concentration & Ref \\
\hline 1. & $\begin{array}{l}\text { Iso-propyl alcohol } \\
\text { (IPA) }\end{array}$ & Bath Sonication & $83{ }^{\circ} \mathrm{C}$ & $0.06 \mathrm{mg} \mathrm{ml}^{-1}$ & 3 \\
\hline 2 & $\begin{array}{l}\text { N-Cyclohexyl-2- } \\
\text { pyrrolidone (CHP) }\end{array}$ & Bath Sonication & $284^{\circ} \mathrm{C}$ & $0.13 \mathrm{mg} \mathrm{ml}^{-1}$ & $3^{*}$ \\
\hline 3 & NMP & Bath Sonication & $202^{\circ} \mathrm{C}$ & $0.031 \mathrm{mg} \mathrm{ml}^{-1}$ & $3^{*}$ \\
\hline 4 & $\mathrm{DMF}$ & Bath Sonication & $153^{\circ} \mathrm{C}$ & $0.024 \mathrm{mg} \mathrm{ml}^{-1}$ & $3^{*}$ \\
\hline 5 & DMSO & Bath Sonication & $189^{\circ} \mathrm{C}$ & $0.036 \mathrm{mg} \mathrm{ml}^{-1}$ & $3^{*}$ \\
\hline 6 & $\begin{array}{l}\text { Water/Ethanol } \\
\text { (45\% water) }\end{array}$ & - & $100^{\circ} \mathrm{C}$ & $0.075 \mathrm{mg} \mathrm{ml}^{-1}$ & 4 \\
\hline 7 & Water & Bath Sonication & $100^{\circ} \mathrm{C}$ & $0.1 \mathrm{mg} \mathrm{ml}^{-1}$ & 5 \\
\hline 8 & DMF & Probe Sonication & $153^{\circ} \mathrm{C}$ & $0.5-1 \mathrm{mg} \mathrm{ml}^{-1}$ & 6 \\
\hline 9 & $\begin{array}{l}\text { Ammonia solution: } \\
\text { IPA 3:2) }\end{array}$ & Bath Sonication & $100^{\circ} \mathrm{C}$ & $0.022 \mathrm{mg} \mathrm{ml}^{-1}$ & 7 \\
\hline 10 & Water & $\begin{array}{l}\text { Bath sonication at } \\
60{ }^{\circ} \mathrm{C}\end{array}$ & $100^{\circ} \mathrm{C}$ & $0.018 \mathrm{mg} / \mathrm{ml}$ & 8 \\
\hline 11 & $\begin{array}{l}\text { Water/ tertiary } \\
\text { Butanol (40:60) }\end{array}$ & Probe Sonication & $100^{\circ} \mathrm{C}$ & $0.213 \mathrm{mg} \mathrm{ml}^{-1}$ & 9 \\
\hline 12 & $\begin{array}{l}\text { Methanesulfonic } \\
\text { acid (MSA) }\end{array}$ & Bath Sonication & $167^{\circ} \mathrm{C}$ & $0.3 \mathrm{mg} \mathrm{ml}^{-1}$ & 10 \\
\hline 13 & $\begin{array}{l}\text { Thionyl } \\
\text { chloride }\left(\mathrm{SOCl}_{2}\right)\end{array}$ & Bath sonication & $75^{\circ} \mathrm{C}$ & $0.4 \mathrm{mg} \mathrm{ml}^{-1}$ & 11 \\
\hline 14 & $\begin{array}{l}\text { Iso-propyl alcohol } \\
\text { (IPA) }\end{array}$ & Probe Sonication & $83^{\circ} \mathrm{C}$ & $0.5 \mathrm{mg} \mathrm{ml}^{-1}$ & 12 \\
\hline 15 & Ionic liquids & Bath Sonication & - & $1.86 \mathrm{mg} \mathrm{ml}^{-1}$ & 13 \\
\hline 16 & $\begin{array}{l}\text { Water/Mono } \\
\text { ethanol amine } \\
(\text { MEA) }(70: 30)\end{array}$ & Bath Sonication & $170^{\circ} \mathrm{C}$ & $1.5 \mathrm{mg} \mathrm{ml}^{-1}$ & 14 \\
\hline 17 & 2- butanone & Probe Sonication & $80^{\circ} \mathrm{C}$ & $3.9 \mathrm{mg} \mathrm{ml}^{-1}$ & $\begin{array}{l}\text { Present } \\
\text { work }\end{array}$ \\
\hline
\end{tabular}


*calculated based on the given data by the authors in the reference

Table S3. Comparison of dielectric performance of $\mathrm{h}-\mathrm{BN}$ based capacitors fabricated employing different processing techniques.

\begin{tabular}{|c|c|c|c|c|c|c|c|c|}
\hline $\begin{array}{l}\text { Sl. } \\
\text { No }\end{array}$ & Processing & $\begin{array}{l}\text { Solvent } \\
\text { used }\end{array}$ & Substrate & $\begin{array}{l}\text { Temper } \\
\text { ature }\end{array}$ & Thickness & $\begin{array}{l}\text { Capacita } \\
\text { nce } \\
\left(\mathrm{nF} / \mathrm{cm}^{2}\right)\end{array}$ & $\begin{array}{l}\text { Dielectric } \\
\text { constant }\end{array}$ & Ref \\
\hline 1 & $\begin{array}{l}\text { Inkjet } \\
\text { printed h- } \\
\text { BN } \\
\text { capacitors } \\
(\mathrm{Ag} / \mathrm{h}- \\
\mathrm{BN} / \mathrm{Ag})\end{array}$ & $\begin{array}{l}\text { Water/ } \\
\text { surfactant }\end{array}$ & $\begin{array}{l}\text { PET } \\
\text { substrate }\end{array}$ & $\begin{array}{l}100^{\circ} \mathrm{C} \\
\text { for } 1 \mathrm{~h}\end{array}$ & $1.2 \mathrm{um}$ & 8.7 & 11.8 & 15 \\
\hline 2 & $\begin{array}{l}\text { Inkjet } \\
\text { printed h- } \\
\text { BN } \\
\text { capacitors } \\
(\mathrm{Gr} / \mathrm{h}- \\
\mathrm{BN} / \mathrm{Gr})\end{array}$ & $\begin{array}{l}\text { Water/ } \\
\text { surfactant }\end{array}$ & $\begin{array}{l}\text { Glass } \\
\text { substrate }\end{array}$ & $\begin{array}{l}150^{\circ} \mathrm{C} \\
\text { for } 2 \mathrm{~h} \\
\text { in } \\
\text { vacuum }\end{array}$ & $3.1 \mathrm{um}$ & 2 & 6.1 & 16 \\
\hline 3 & $\begin{array}{l}\text { CVD } \\
\text { grown h- } \\
\text { BN } \\
\text { capacitors } \\
(\mathrm{Au} / \mathrm{h}- \\
\mathrm{Bn} / \mathrm{Au})\end{array}$ & - & $\begin{array}{l}\text { PET } \\
\text { substrate }\end{array}$ & $\begin{array}{l}850^{\circ} \mathrm{C} \\
\text { for } 3 \mathrm{~h}\end{array}$ & $30 \mathrm{~nm}$ & 6800 & 230 & 17 \\
\hline 4 & $\begin{array}{l}\text { Spray } \\
\text { printed h- } \\
\text { BN layer } \\
\text { (Gr/h-BN } \\
\text { /graphene) }\end{array}$ & IPA & $\begin{array}{l}\text { Alumina } \\
\text { coated } \\
\text { PET } \\
\text { substrate }\end{array}$ & - & $1.8 \mathrm{um}$ & 0.75 & 1.5 & 12 \\
\hline 5 & $\begin{array}{l}\mathrm{LBL} \\
\text { assembled } \\
\text { h-BN } \\
\text { capacitors } \\
(\mathrm{Si} / \mathrm{SiO} 2 / \mathrm{h}- \\
\mathrm{BN} / \mathrm{Au})\end{array}$ & $\begin{array}{l}\text { Water/ } \\
\text { surfactant }\end{array}$ & $\mathrm{Si} / \mathrm{SiO}_{2}$ & $\begin{array}{l}600^{\circ} \mathrm{C} \\
\text { in air }\end{array}$ & $7 \mathrm{~nm}$ & 245 & 2 & 18 \\
\hline 6 & $\begin{array}{l}\text { Electrophor } \\
\text { etic } \\
\text { depoted h- } \\
\text { BN (ITO/h- } \\
\text { BN/Al) }\end{array}$ & $\begin{array}{l}2- \\
\text { butanone }\end{array}$ & PET & $\begin{array}{l}\text { Room } \\
\text { Temper } \\
\text { ature }\end{array}$ & $27 \mathrm{~nm}$ & 175 & 5 & $\begin{array}{l}\text { Present } \\
\text { work }\end{array}$ \\
\hline
\end{tabular}




\section{References:}

1. O’Neill, A.; Khan, U.; Coleman, J. N., Preparation of high concentration dispersions of exfoliated $\mathrm{MoS}_{2}$ with increased flake size. Chem. Mater., 2012, 24 (12), 2414-2421.

2. Backes, C.; Higgins, T. M.; Kelly, A.; Boland, C.; Harvey, A.; Hanlon, D.; Coleman, J. N., Guidelines for exfoliation, characterization and processing of layered materials produced by liquid exfoliation. Chem. Mater. 2016, 29 (1), 243-255.

3. Coleman, J. N.; Lotya, M.; O’Neill, A.; Bergin, S. D.; King, P. J.; Khan, U.; Young, K.; Gaucher, A.; De, S.; Smith, R. J., Two-dimensional nanosheets produced by liquid exfoliation of layered materials. Science 2011, 331 (6017), 568-571.

4. Zhou, K. G.; Mao, N. N.; Wang, H. X.; Peng, Y.; Zhang, H. L., A mixed-solvent strategy for efficient exfoliation of inorganic graphene analogues. Angew. Chem. Int. Ed. 2011, 50 (46), 10839-10842.

5. Lin, Y.; Williams, T. V.; Xu, T.-B.; Cao, W.; Elsayed-Ali, H. E.; Connell, J. W., Aqueous dispersions of few-layered and monolayered hexagonal boron nitride nanosheets from sonication-assisted hydrolysis: critical role of water. J. Phys. Chem. C 2011, 115 (6), 2679-2685.

6. Zhi, C.; Bando, Y.; Tang, C.; Kuwahara, H.; Golberg, D., Large-scale fabrication of boron nitride nanosheets and their utilization in polymeric composites with improved thermal and mechanical properties. Adv. Mater. 2009, 21 (28), 2889-2893.

7. Cao, L.; Emami, S.; Lafdi, K., Large-scale exfoliation of hexagonal boron nitride nanosheets in liquid phase. Mater. Express. 2014, 4 (2), 165-171.

8. Kim, J.; Kwon, S.; Cho, D.-H.; Kang, B.; Kwon, H.; Kim, Y.; Park, S. O.; Jung, G. Y.; Shin, E.; Kim, W.-G., Direct exfoliation and dispersion of two-dimensional materials in pure water via temperature control. Nat. Commun. 2015, 6, 8294.

9. Habib, T.; Sundaravadivelu Devarajan, D.; Khabaz, F.; Parviz, D.; Achee, T. C.; Khare, R.; Green, M. J., Cosolvents as Liquid Surfactants for Boron Nitride Nanosheet (BNNS) Dispersions. Langmuir 2016, 32 (44), 11591-11599.

10. Wang, Y.; Shi, Z.; Yin, J., Boron nitride nanosheets: large-scale exfoliation in methanesulfonic acid and their composites with polybenzimidazole. J. Mater. Chem. 2011, 21 (30), 11371-11377.

11. Sun, W.; Meng, Y.; Fu, Q.; Wang, F.; Wang, G.; Gao, W.; Huang, X.; Lu, F., Highyield production of boron nitride nanosheets and its uses as a catalyst support for 
hydrogenation of nitroaromatics. ACS Appl. Mater. Interfaces 2016, 8 (15), 98819888.

12. Kelly, A. G.; Finn, D.; Harvey, A.; Hallam, T.; Coleman, J. N., All-printed capacitors from graphene-BN-graphene nanosheet heterostructures. Appl. Phys. Lett. 2016, 109 (2), 023107.

13. Morishita, T.; Okamoto, H.; Katagiri, Y.; Matsushita, M.; Fukumori, K., A high-yield ionic liquid-promoted synthesis of boron nitride nanosheets by direct exfoliation. Chem. Commun. 2015, 51 (60), 12068-12071.

14. Zhang, B.; Wu, Q.; Yu, H.; Bulin, C.; Sun, H.; Li, R.; Ge, X.; Xing, R., HighEfficient Liquid Exfoliation of Boron Nitride Nanosheets Using Aqueous Solution of Alkanolamine. Nanoscale Res. Lett. 2017, 12 (1), 596.

15. Carey, T.; Cacovich, S.; Divitini, G.; Ren, J.; Mansouri, A.; Kim, J. M.; Wang, C.; Ducati, C.; Sordan, R.; Torrisi, F., Fully inkjet-printed two-dimensional material field-effect heterojunctions for wearable and textile electronics. Nat. Commun. 2017, $8(1), 1202$.

16. Worsley, R.; Pimpolari, L.; McManus, D.; Ge, N.; Ionescu, R.; Wittkopf, J. A.; Alieva, A.; Basso, G.; Macucci, M.; Iannaccone, G., All-2D Material Inkjet-Printed Capacitors: Toward Fully Printed Integrated Circuits. ACS Nano 2019, 13 (1), 54-60.

17. Guo, N.; Wei, J.; Jia, Y.; Sun, H.; Wang, Y.; Zhao, K.; Shi, X.; Zhang, L.; Li, X.; Cao, A., Fabrication of large area hexagonal boron nitride thin films for bendable capacitors. Nano Res. 2013, 6 (8), 602-610.

18. Zhu, J.; Kang, J.; Kang, J.; Jariwala, D.; Wood, J. D.; Seo, J.-W. T.; Chen, K.-S.; Marks, T. J.; Hersam, M. C., Solution-processed dielectrics based on thickness-sorted two-dimensional hexagonal boron nitride nanosheets. Nano Lett. 2015, 15 (10), 70297036. 